\title{
Simulation of Masonry Wall using Concrete Damage Plasticity Model
}

\author{
Suraj D. Bhosale, Atul K. Desai
}

\begin{abstract}
The objective of this article is to study the use of FE (Finite Element) tool in analyzed the masonry wall. Masonry is made up of highly nonlinear material and its property varies from place to place. It is difficult to do an experiment on a full-scale model of a masonry wall. Its effect is also underestimated in construction of low rise building. As if the wall is confined and properly bonded to the beam and column. It enhances the performance of low rise building during seismic forces. As in low rise building energy is dissipated by cracking. If masonry wall is cast monolithically (like confined masonry) with the column, it augments the stiffness of building and helps to sustain additional load compare to conventional construction practice. In this study numerical nonlinear analysis of wall panel is done by $F E$ tool (ABAQUS). Using Concrete Damage Plasticity Model (CDP). And results are compared with the existing work done by other researchers and it is observed that results were satisfactory.
\end{abstract}

Keywords - Finite Element (FE), Concrete Damage Plasticity (CDP), Masonry wall.

\section{INTRODUCTION}

It was observed that from many decades masonry wall was considered as an only partition wall and it is not considered as a structural member in RCC frame structure. But in recent studies it was found that up to a few stories, we can use confined masonry wall. Up to three storey (floor to floor height 10 feet) building. It is observed by researchers that confined masonry is economical and effective then RCC frame structure up to three stories. Seismic response of structures to strong earthquake frequently produces excessive and uncontrollable lateral displacement as well as serious damages to structural and non-structural elements [1]. Masonry is classified as heterogeneous anisotropic material and analysis, understanding and capture of the structural behaviour of masonry are therefore complex. [2].

Revised Manuscript Received on July 25, 2019

Suraj D. Bhosale

Research Scholar, Applied Mechanics Department, Sardar Vallbhbhai

National Institute of Technology, Surat, Gujarat, India.

Email- bhosalesurajd@gmail.com

Dr. Atul K. Desai,

Professor, Applied Mechanics Department, Sardar Vallbhbhai National Institute of Technology, Surat, Gujarat, India.

Email- atuldesai61@gmail.co

\section{FEM MODELLING}

\subsection{Type of modelling}

There is three types of modelling of masonry done is done FE tool. They are 1. Micro modelling in which thickness of mortar and brick/unit both are considered and analysis is carried out. As it is more accurate but difficult to model and time-consuming.

2. Simplified micro modelling approach in this modelling is simple then micro modelling and thickness of mortar are not visualised as unit thickness interface is provided between units/bricks. 3. Macro modelling in this whole wall is considered as homogeneous and it is the fastest way to analyses the wall but results and not accurate as observed.

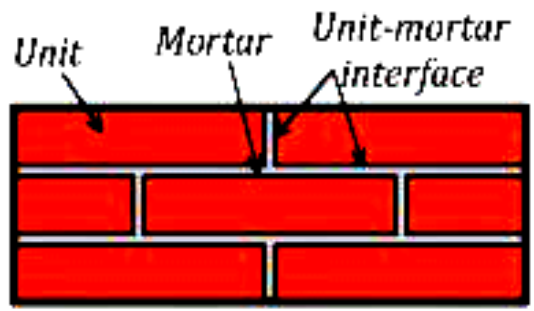

(a)

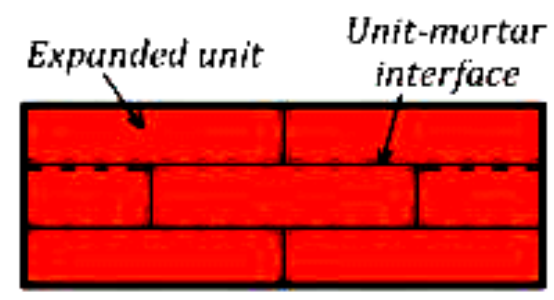

(b)

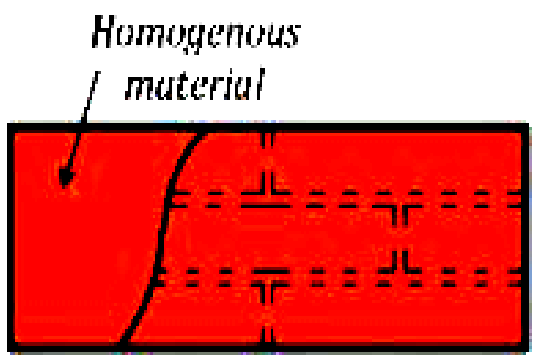

(c)

Figure 1. FE Modelling Approaches (a) Micro Modelling (b) Simplified Micro Modelling. (c) Macro Modelling [1] 


\section{FE Modelling and Analysis}

In present simplified micro modelling approach. 3D hexahedral shaped eight node brick element with hour glass control (C3D8R) is used in modelling.[2] The interface is defined as a surface-based cohesive interface. Contact between adjacent masonry is General explicit surface to surface based contact. Model is generated in Abaqus standard/explicit, mesh size is chosen based on mesh analysis study. Where mesh size is changed and results are compared and we found that current provided mesh size gives an optimum solution with less time consumption. i.e. $6 \times 2 \times 3$ element in a brick/unit. The dimension of the unit available in the locality was $195 \mathrm{~mm}$ x $90 \mathrm{~mm} \times 70 \mathrm{~mm}$. So same dimension are been modelled. Thirteen courses high and $780 \mathrm{~mm}$ width single brick masonry wall is modelled.

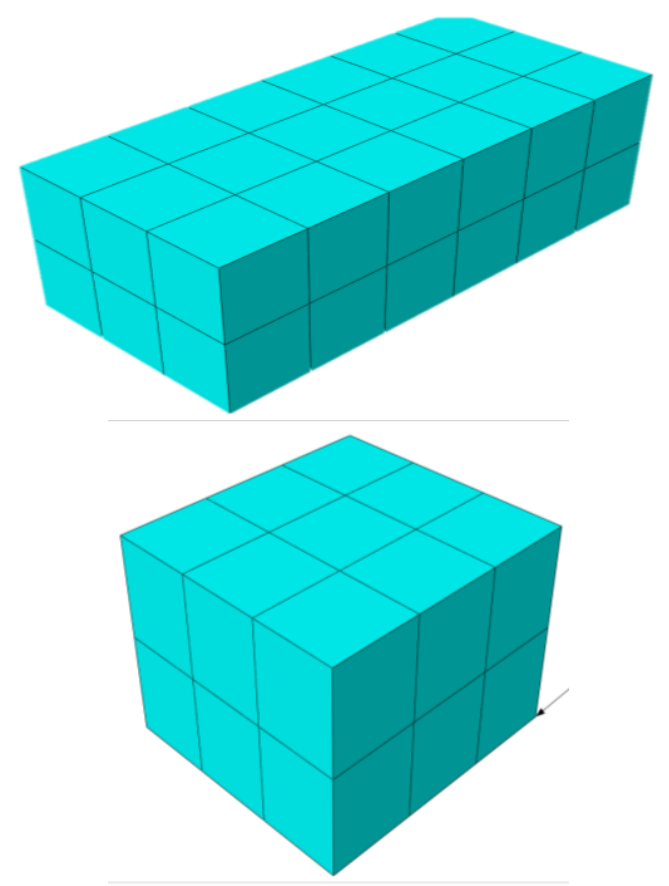

Figure 2. Brick/Unit Mesh Size with C3D8R element.

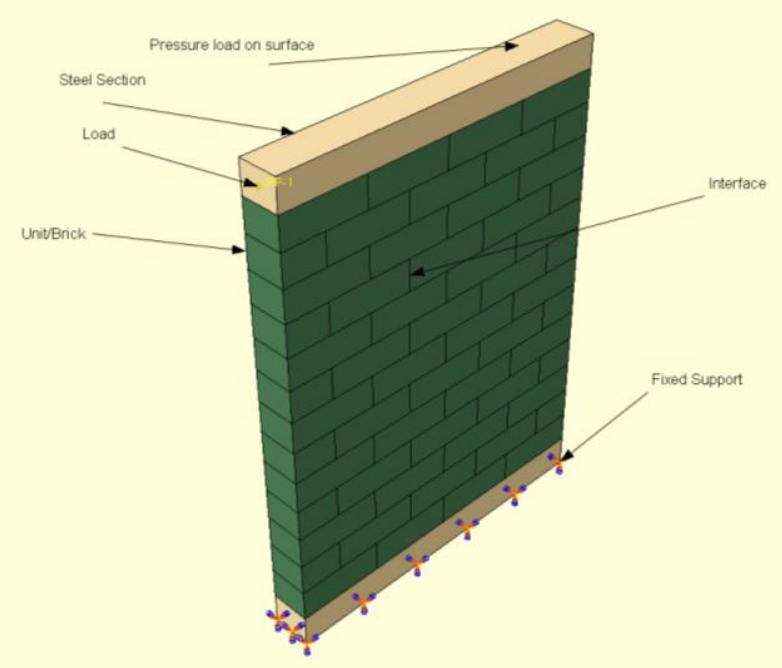

Figure 3. Model of Masonry in Abaqus with other details.

Figure 3 shows the material properties of masonry and steel separation in modelling and location of loads. Based is fixed and vertical pressure is applied in the initial step and lateral load is applied in the second stage where coupling contact is defined. At the centre of the steel section as shown in Fig. 3.

\section{Material Properties}

Brick/unit properties are determined experimentally. Density of brick $\delta$ and Poisson ratio $\mu$ for brick is 1900 $\mathrm{kg} / \mathrm{m}^{3}$ and 0.15 respectively whereas $\mathrm{E}=3.98 \times 10^{9} \mathrm{~N} / \mathrm{m}^{2}$. Steel $\mathrm{E}=210 \times 10^{9} \mathrm{~N} / \mathrm{m}^{2}$ and $\mu=0.3$. As provided by the manufactural.

Table 1. Concrete Damage Plasticity Material Property

\begin{tabular}{|l|c|}
\hline Dilation Angle & 10 \\
\hline Eccentricity & 0.1 \\
\hline $\mathrm{F}_{\mathrm{bo}} / \mathrm{F}_{\mathrm{co}}$ & 1.16 \\
\hline Viscosity & 0.002 \\
\hline
\end{tabular}

Lateral load of $6600 \mathrm{~N}$ was applied on the steel section connected on the top of the masonry in the second step and an initial step a pressure force of $240000 \mathrm{~N} / \mathrm{m}^{2}$ was given. Dynamic Explicit Model was used in the step.

Table 2. Interface Property.

\begin{tabular}{|l|c|}
\hline $\begin{array}{l}\text { Tangential Behavior } \\
\text { Frictional co efficient }\end{array}$ & 0.7 \\
\hline $\begin{array}{l}\text { Maximum Nominal Stress in } \\
\text { Normal Direction }\end{array}$ & $61100 \mathrm{~N} / \mathrm{m}^{2}$ \\
\hline $\begin{array}{l}\text { Maximum Nominal Stress in } \\
\text { Shear Direction -I }\end{array}$ & $93350 \mathrm{~N} / \mathrm{m}^{2}$ \\
\hline $\begin{array}{l}\text { Maximum Nominal Stress in } \\
\text { Shear Direction -II }\end{array}$ & $93350 \mathrm{~N} / \mathrm{m}^{2}$ \\
\hline Plastic Displacement & $0.001 \mathrm{~m}$ \\
\hline Exponential Parameter & 10 \\
\hline Viscosity & 0.002 \\
\hline
\end{tabular}

\section{SIMULATION RESULT AND VALIDATION}

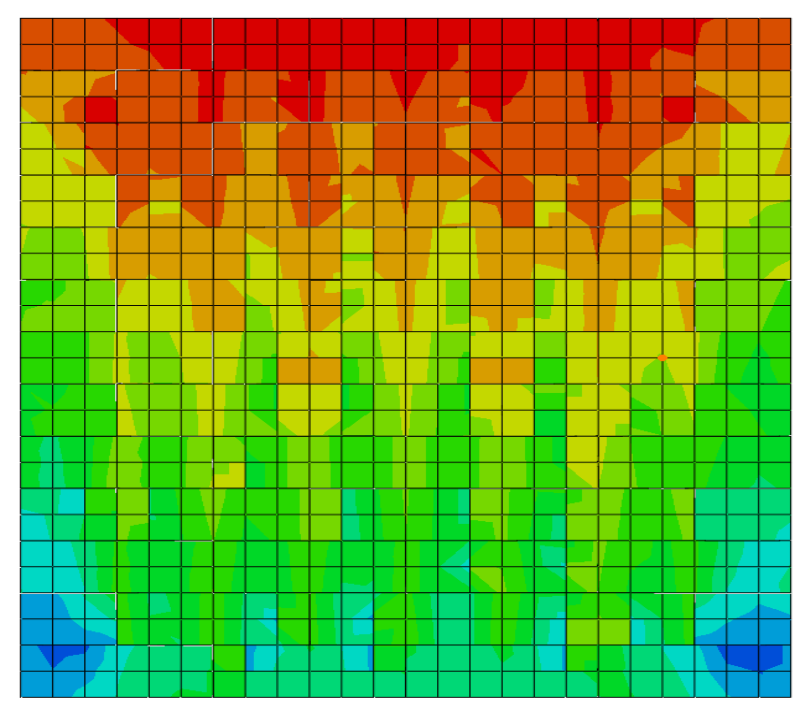

Figure 3. (a) shows the vertical stress in masonry during the initial step where only vertical pressure is applied and no failure was observed in the analysis of the model.

\section{Published By:}




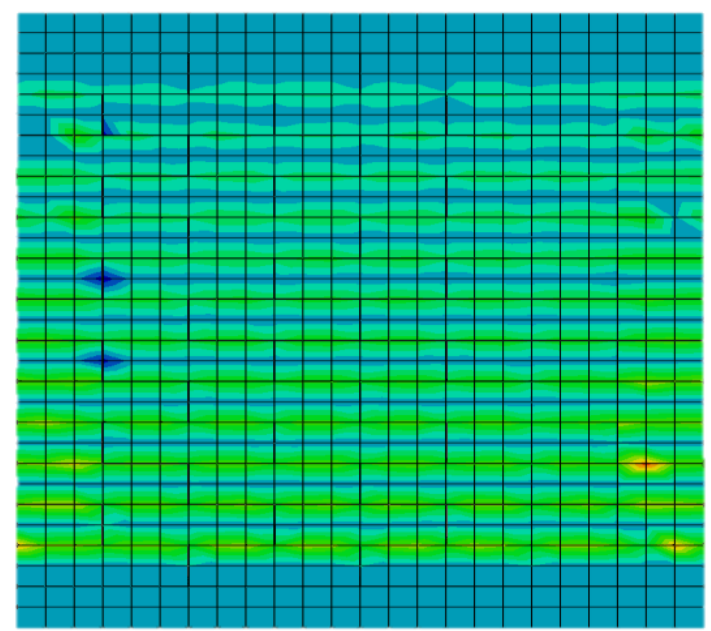

Figure 3. (b) shows the horizontal stress in masonry during the step where only horizontal pressure is applied and no failure was observed in the analysis of the model.

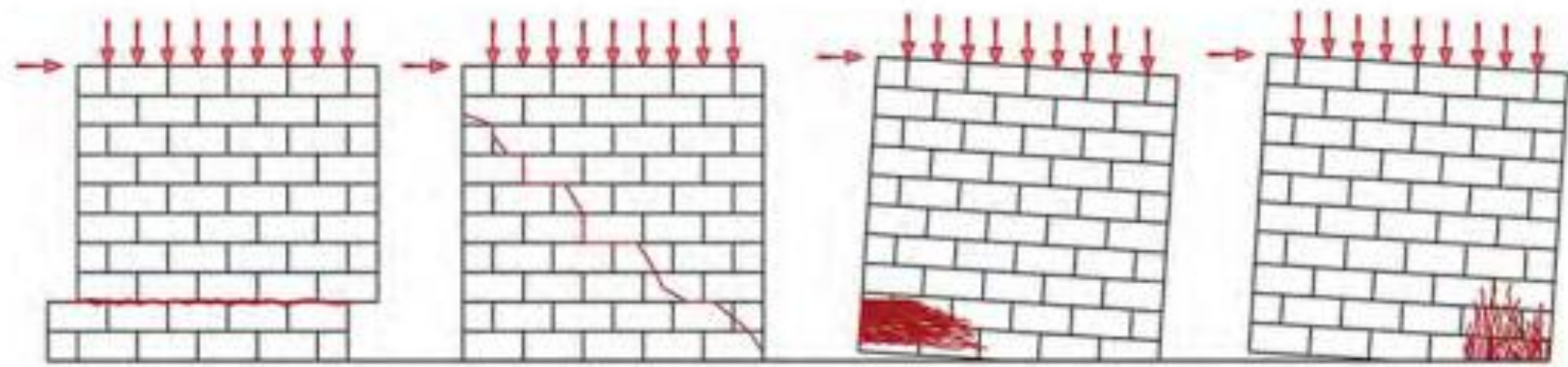

(a)

(b)

(c)

(d)

Figure 4. shows the rocking failure and toe-crushing ar per the researcher has found failure in masonry in seismic loading.[5]

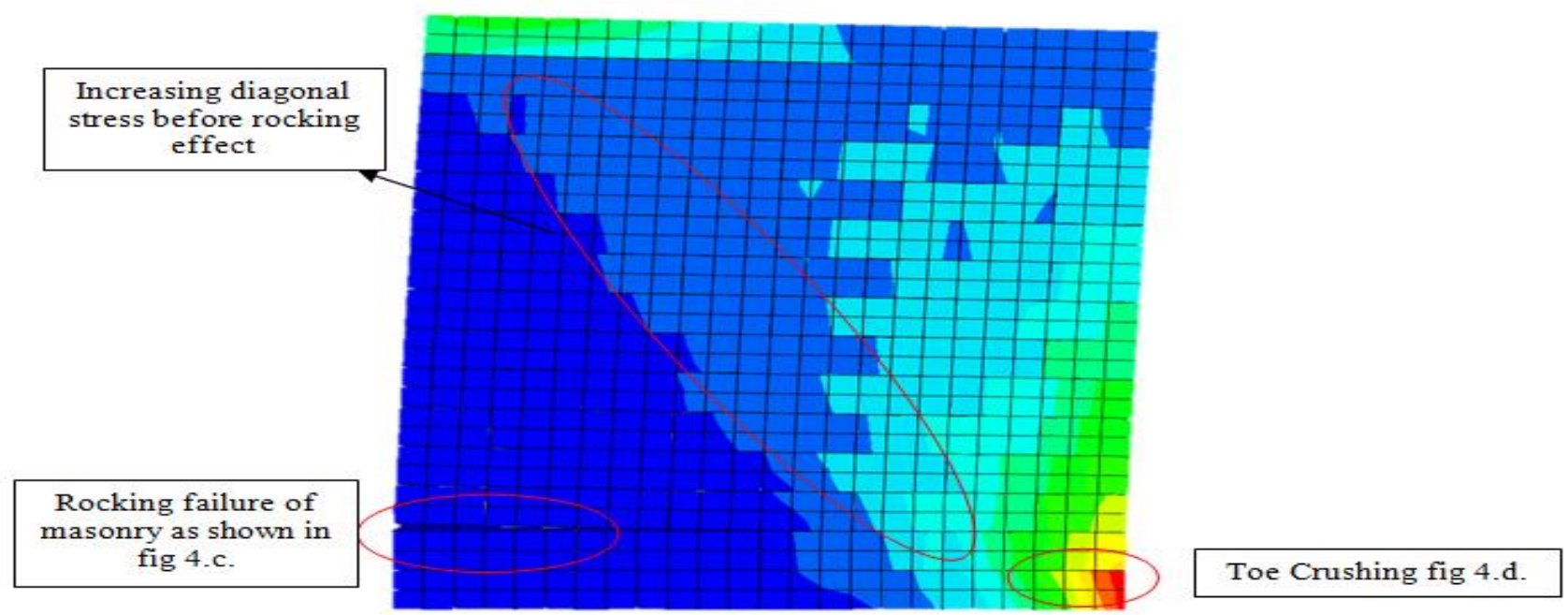

Figure 5. shows the rocking failure, toe-crushing and stress in FEM model analysis in abaqus.

Simulation results and failure pattern shown by the author are similar and validate the results by concrete damage plasticity model. This can be a new method and approach to analysing the masonry wall.

\section{IV.CONCLUSION}

Numerical analysis of masonry wall by simplified micro model approach is a better way to analyse masonry. And beneficial were to perform the experiment is not convenient. Rocking failure was dominant here in this study. If the bond between masonry and mortar is strong might be possible that diagonal crack will be a dominant failure in the same masonry.

It gives accurate results and has validated with the author. As masonry is highly nonlinear and varieties of masonry units are available CDP model has validated the brick masonry model. Might not be valid to stone masonry or block masonry.

\section{Published By:}

Blue Eyes Intelligence Engineering 


\section{REFERENCES}

[1] M. Teguh, "Experimental Evaluation of Masonry Infill Walls of RC Frame Buildings Subjected to Cyclic Loads," Procedia Eng., vol. 171, pp. 191-200, 2017.

[2] K. F. Abdulla, L. S. Cunningham, and M. Gillie, "Simulating masonry wall behaviour using a simplified micro-model approach," Eng. Struct., vol. 151, pp. 349-365, 2017.

[3] M. Resta, A. Fiore, and P. Monaco, "Non-Linear Finite Element Analysis of Masonry Towers by Adopting the Damage Plasticity Constitutive Model,” Adv. Struct. Eng., vol. 16, no. 5, pp. 791-803, May 2013.

[4] H. Jiang, X. Liu, and J. Mao, "Full-scale experimental study on masonry infilled RC moment-resisting frames under cyclic loads," Eng. Struct., vol. 91, 2015

[5] R. Oyguc and E. Oyguc, "2011 Van Earthquakes: Lessons from Damaged Masonry Structures," J. Perform. Constr. Facil., vol. 31, no. 5, p. 04017062 , Apr. 2017.

[6] N. N. Thaickavil and J. Thomas, "Behaviour and strength assessment of masonry prisms," Case Stud. Constr. Mater., 2018.

[7] T. Kanayama, "Taxonomy and phylogeny of the family Agonidae (Pisces: Scorpaeniformes).," Mem. Fac. Fish. Hokkaido Univ., vol. 38, no. 12, pp. 1-199, 1991.

[8] S. Noor-E-Khuda, M. Dhanasekar, and D. P. Thambiratnam, "Outof-plane deformation and failure of masonry walls with various forms of reinforcement," Compos. Struct., vol. 140, pp. 262-277, 2016.

[9] T. Sevil, M. Baran, T. Bilir, and E. Canbay, "Use of steel fiber reinforced mortar for seismic strengthening," Constr. Build. Mater., vol. 25, no. 2, pp. 892-899, 2011.

[10] Y.-F. Wu and M. P. Dare, "Axial and Shear Behavior of Glass Fiber Reinforced Gypsum Wall Panels: Tests,” J. Compos. Constr., vol. 8, no. 6, pp. 569-578, 2004.

[11] T. Stablon, A. Sellier, N. Domede, B. Plu, and L. Dieleman, "Influence of building process on stiffness: Numerical analysis of a masonry vault including mortar joint shrinkage and crack re-closure effect," Mater. Struct. Constr., vol. 45, no. 6, pp. 881-898, 2012.

[12] S. Noor-E-Khuda and M. Dhanasekar, "Masonry walls under combined in-plane and out-of-plane loadings," J. Struct. Eng., vol. 144, no. 2, pp. 1-10, 2018

[13] S. Nazir and M. Dhanasekar, "Modelling the failure of thin layered mortar joints in masonry,” Eng. Struct., vol. 49, pp. 615-627, 2013.

[14] L. C. Silva, P. B. Lourenço, and G. Milani, "Nonlinear Discrete Homogenized Model for Out-of-Plane Loaded Masonry Walls," J. Struct. Eng., vol. 143, no. 9, p. 04017099, 2017.

[15] T. Yi, F. L. Moon, R. T. Leon, and L. F. Kahn, "Analyses of a TwoStory Unreinforced Masonry Building,” J. Struct. Eng., vol. 132, no. 5, pp. 653-662, 2006.

[16] C. Wang, J. P. Forth, N. Nikitas, and V. Sarhosis, "Retrofitting of masonry walls by using a mortar joint technique; experiments and numerical validation,” Eng. Struct., vol. 117, pp. 58-70, 2016.

[17] J. Proença, A. S. Gago, J. Cardoso, V. Cóias, and R. Paula, "Development of an innovative seismic strengthening technique for traditional load-bearing masonry walls," Bull. Earthq. Eng., vol. 10, no. 1, pp. 113-133, 2012.

[18] P. Sartaji, A. S. Moghadam, and M. Ghafory Ashtiany, "Interaction of masonry walls and shear walls in masonry buildings," Proc. Inst. Civ. Eng. Struct. Build., vol. 171, no. 3, pp. 226-240, 2018.

[19] G. de Felice et al., "Experimental characterization of composite-tobrick masonry shear bond," Mater. Struct. Constr., vol. 49, no. 7, pp. 2581-2596, 2016.

[20] M. A. Kyriakides and S. L. Billington, "Behavior of unreinforced masonry prisms and beams retrofitted with engineered cementitious composites," Mater. Struct. Constr., vol. 47, no. 9, pp. 1573-1587, 2014.

[21] B. H. Pandey and K. Meguro, "Simulation of brick masonry wall behavior under in-plane lateral loading using applied element method," 13th World Conf. Earthq. Eng. Vancouver, BC, Canada, August, no. 1664, pp. 1-6, 2004.

[22] H. Okail, A. Abdelrahman, A. Abdelkhalik, and M. Metwaly, "Experimental and analytical investigation of the lateral load response of confined masonry walls," HBRC J., vol. 12, no. 1, pp. 33-46, 2016.

[23] H. B. Kaushik, D. C. Rai, and S. K. Jain, "Code approaches to seismic design of masonry-infilled reinforced concrete frames: A state-of-the-art review," Earthq. Spectra, vol. 22, no. 4, pp. 961983,2006

[24] K. Shahzada et al., "Experimental seismic performance evaluation of unreinforced brick masonry buildings," Earthq. Spectra, 2012.

[25] M. B. Ravula and K. V. L. Subramaniam, "Investigation of Compression Failure in Brick," no. 1, pp. 1-9, 2017.

[26] K. S. Jagadish, S. Raghunath, and K. S. Nanjunda Rao, "Behaviour of masonry structures during the Bhuj earthquake of January 2001,"
Proc. Indian Acad. Sci. Earth Planet. Sci., vol. 112, no. 3, pp. 431440, 2003

[27] S. Y. Wang, S. W. Sloan, A. J. Abbo, M. J. Masia, and C. A. Tang, "Numerical simulation of the failure process of unreinforced masonry walls due to concentrated static and dynamic loading," Int. J. Solids Struct., vol. 49, no. 2, pp. 377-394, 2012.

[28] V. Sarhosis, S. W. Garrity, and Y. Sheng, "Influence of brickmortar interface on the mechanical behaviour of low bond strength masonry brickwork lintels," Eng. Struct., vol. 88, pp. 1-11, 2015.

[29] C. V. R. Murty and S. K. Jain, "Beneficial Influence of Masonry Infill Walls on Seismic Performance of Rc Frame Buildings," Twelfth World Conf. Earthq. Eng., pp. 1-6, 2000. 